\section{Vladimir Mićić}

Ekonomski fakultet Univerziteta u Kragujevcu micicv@kg.ac.rs

Nenad Janković

Ekonomski fakultet Univerziteta u Kragujevcu njankovic@kg.ac.rs

\section{INVESTICIJE U PRERAĐIVAČKOJ INDUSTRIJI SRBIJE}

\title{
Rezime
}

Intenzitet i efikasnost investicija u fiksne fondove prerađivačke industrije su jedan od osnovnih faktora održivog rasta BDP i sprovođenja strukturnih promena. Zemlje u razvoju i tranziciji, sa niskim nivoom bruto domaćeg proizvoda per capita ne mogu da smanje ekonomsko zaostajanje za razvijenim zemljama bez bržeg rasta i povećanja intenziteta i efikasnosti investicija u prerađivačkoj industriji. Stoga su predmet istraživanja ovoga rada implikacije investicija u fiksne fondove prerađivačke industrije Srbije. Cilj istraživanja u radu je da ukaže na značaj efikasnog sprovođenja investicione politike, kao i na važnost investicija kao sredstva sprovođenja industrijske politike. Centralno pitanje je kakvi su efekti investicija u osnovne fondove prerađivačke industrije Srbije. Može se zaključiti da je i pored rasta nivo investicija nizak u odnosu na razvojne potrebe i privrede i prerađivačke industrije. U narednom periodu neophodno je više se oslanjati na sopstvene snage, domaću štednju i povećati efikasnost investicija zbog tehnološke modernizacije, rasta produktivnosti i konkurentnosti sektora prerađivačke industrije Srbije.

Ključne reči: investicije u osnovne fondove, prerađivačka industrija, strukturne promene

JEL: E22, L16 O14, O47 


\section{INVESTMENT IN THE}

Vladimir Mićić

Faculty of Economics, University of Kragujevac micicv@kg.ac.rs

\section{Nenad Janković}

Faculty of Economics, University of Kragujevac njankovic@kg.ac.rs

\section{Summary}

The intensity and efficiency of fixed investment in the manufacturing industry are among the basic factors of sustainable GDP growth and structural changes implementation. The developing and transition countries, with low GDP per capita, cannot catch up with the developed economies without accelerated growth and increased intensity and efficiency of investment in the manufacturing industry. For that reason, this paper's research focuses on the implications of fixed investment in the manufacturing industry of Serbia. The objective of this paper is to highlight how significant it is to efficiently implement investment policy, as well as how important investment is as a means of conducting the industry policy. The central question refers to the effects of investment in the fixed assets of the manufacturing industry of Serbia. It can be concluded that, despite its growth, the investment remains low in comparison with the development needs of both the economy and the manufacturing industry. In the forthcoming period it is necessary to increasingly rely on one's own strengths, domestic savings, and to boost the efficiency of investment aimed at technological modernization, growing productivity and competitiveness of the manufacturing industry in Serbia.

Keywords: investment in fixed assets, manufacturing industry, structural changes

JEL: E22, L16 O14, O47 


\section{Uvod}

Uzemljama u razvoju i tranziciji, poputSrbije, investicije u osnovne (fiksne) fondove industrije su jedan od osnovnih faktora održivog rasta $\mathrm{BDP}$, posebno investicije u osnovne fondove sektora prerađivačke industrije. Njihov važan zadatak jeste povećanje ovih investicija kako bi se povećali proizvodni kapaciteti i povećala zaposlenost (Rowthorn, 1995). Povećanje investicija u osnovne fondove, tehnološke inovacije i nove tehnologije od suštinskog su značaja za pokretanje strukturnih promena, rast produktivnosti i konkurentnosti i rast izvoza (UNIDO, 2015). Posebno su značajne investicije iz domaćih izvora ili akumulacije, zbog čega je neophodno da štede svi ekonomski subjekti.

Akumulacija (kapital) za finansiranje ekonomskog razvoja može biti angažovana i iz inostranstva, kako u formi portfolio investicija, stranih direktnih investicija (SDI), tako i u formi klasičnog pozajmljivanja. Intenzitet međunarodnog kretanja kapitala se menjao tokom vremena. Periode ekonomske stabilnosti i prosperiteta karakteriše pojačano međunarodno kretanje kapitala, dokekonomske krize i političku nestabilnost, obeležava smanjenje tokova međunarodnog kretanja kapitala (poput svetske finansijske i ekonomske krize iz 2008. godine). Pored toga, različite periode karakteriše dominacija različitih oblika međunarodnog kretanja kapitala.

Zbog kulminacije dužničke krize i globalizacije koja je prisutna u svim poljima, može se reći da SDI (naročito u zemljama u razvoju i tranziciji) preuzimaju funkciju ključnog razvojnog faktora. SDI predstavljaju najrizičniji vid ulaganja za investitora, ali i način ulaganja koji potencijalno donosi najveći profit. Pored tog profita koji je bitan, investitor ima i odlučujuću ulogu u upravljanju sopstvenom investicijom. Zašto je ovaj vid ulaganja posebno značajan za privredni rast i razvoj zemalja u razvoju i tranziciji? Osnovni razlog je postojanje raskoraka između potreba i mogućnosti ovih zemalja. Postoji značajan nedostatak investicionih sredstava zato što su to zemlje sa niskim BDP i skromnim akumulativnim mogućnostima. Pored toga, ukoliko se govori o zemljama u tranziciji, prelazak na tržišnu privredu je skup i zahteva velika ulaganja radi strukturnih i institucionalnih prilagođavanja. Dosadašnja ekonomska istraživanja su pokazala da su SDI igrale značajnu ulogu u strukturnim promenama proizvodnje i izvoza u zemljama korisnicima ovih sredstava. Naročito u zemljama koje iz nekog razloga imaju otežan pristup međunarodnom tržištu kapitala (Veselinović, 2004, 42). SDI poseduju jak razvojni potencijal (Antevski, 2008, 88). Efekti stranih ulaganja su uglavnom pozitivni i obostrani (Antevski, 2009, 51-52). Ipak, motivi za privlačenje SDI se među zemljama razlikuju zavisno od njihovog razvojnog nivoa. Nerazvijene zemlje, siromašne kapitalom računaju na brojne pozitivne efekte koje SDI daju, prihvatajući često i negativne (Jovanović Gavrilović, 2012, 216).

\section{Investicije u osnovne (fiksne) fondove industrije - teorijski aspekt}

Osnovni (fiksni) fondovi ili osnovna sredstva predstavljaju materijalna i nematerijalna sredstva koja se koriste u procesu proizvodnje. Formiraju se ulaganjem kapitala koji se štedi i investira tako da oni predstavljaju fond vrednosti, dok su štednja i investicije tok vrednosti. Investicije znače ulaganje kapitala u neki unosan posao koji doprinosi stvaranju nove vrednosti (Ilić, et al., 2003). Srž investicija i investiranja čini odricanje od tekuće (finalne) potrošnje dela BDP, radi povećanja BDP, potrošnje i koristi u budućnosti.

Investiranje podrazumeva proces ulaganja kapitala u investicije, dok finansiranje investicija predstavlja pribavljanje finansijskih izvora i obezbeđivanje kapitala (Savić, et al., 2015). Za finansiranje investicija u prerađivačkoj industriji postoje interni i eksterni izvori (Faulkender \& Petersen, 2006). Brojni autori ukazuju da zemlje koje imaju razvijene finansijske sisteme i tržište kapitala (Erić, et al., 2012), pored tradicionalnih imaju mnogo više mogućnosti za finansiranje investicija putem alternativnih izvora (Gompers \& Lerner, 2001), kao što su rizični kapital (Hellmann \& Puri, 2000) i privatni investicioni fondovi (Inderst, 2013). Razvijena finansijska tržišta poboljšavaju alokaciju kapitala i povećavaju investicije $u$ rastućim, a smanjuju u opadajućim industrijama (Wurgler, 2000).

Bez obzira da li se posmatraju u užem (Sokoloff, 1984) ili širem smislu (Chen, et al., 


\section{Introduction}

In developing and transition countries, like Serbia, investment in the fixed assets of industry is among the main factors of sustainable GDP growth, especially investment in the fixed assets of the manufacturing industry. It is, thus, an important task to increase these investments in order to boost production capacities and create new jobs (Rowthorn, 1995). Increased investment in the fixed assets, technological innovations and advanced technologies is of essential importance for triggering structural changes, growth of productivity and competitiveness, along with the growing export (UNIDO, 2015). Particularly significant are the investments from domestic sources or accumulation, which is why it is necessary for all economic entities to resort to savings.

Accumulation (i.e. capital) for financing the economic development can also be engaged from abroad, in the form of portfolio investment, foreign direct investment (FDI), or classic borrowing. The intensity of international capital flows has been changing over the years. The periods of economic stability and prosperity have been characterized by intensified crossborder capital flows, whereas the economic crises and political instability have been marked by reduced cross-border activity in terms of capital flows (like during the 2008 global financial and economic crisis). Moreover, different periods have been characterized by the domination of different forms of international capital flows.

Due to the culmination of the debt crisis and omnipresent globalization, it can be said that FDI (especially in the developing and transition countries) has been taking over the function of the key development factor. FDI is the riskiest form of investment for investors, but at the same time they potentially entail the highest profit. In addition to the profit, which certainly is important, investors have the decisive role in managing their own investment. Why is this form of investment so important for the economic growth and development of the developing and transition countries? The main reason is the existing discrepancy between the needs and possibilities of these countries. There is a substantial lack of investment funds because these countries have low GDP and modest accumulation capacity. Furthermore, in the case of transition countries, the transition to market economy is expensive and requires major investments for the purpose of structural and institutional adjustments. The economic research conducted so far has shown that FDI has played a significant role in the structural changes of production and export in the countries using these funds. This was particularly the case in the countries which, for some reason, have limited access to the international capital market (Veselinović, 2004, 42). FDI contains a powerful development potential (Antevski, 2008, 88). The effects of foreign investment are mostly positive and mutual (Antevski, 2009, 51-52). Nevertheless, the motivation for attracting FDI differs among the countries depending on their development level. The developing countries, poor in capital, count on the numerous positive effects of FDI, often accepting the negative ones as well (Jovanović Gavrilović, 2012, 216).

\section{Investment in the Fixed Assets of the Industry - Theoretical Aspect}

Capital (fixed) assets refer to the tangible and intangible assets used in the production process. They are formed by means of investment of capital which is accumulated and further invested, hence they represent the value fund, whereas savings and investments represent the value flow. Investment refers to the investment of capital into a profitable business which contributes to the generation of the new value (Ilić, et al., 2003). The core principle of investing is the renouncement of the current (final) spending of a segment of GDP, for the purpose of increasing GDP, spending and benefits in the future.

Investment is the process of investing capital, whereas investment financing implies the acquisition of sources of finance and procurement of capital (Savić, et al., 2015). For the purpose of financing investment in the manufacturing industry there are both internal and external sources (Faulkender \& Petersen, 2006). Numerous authors indicate that the countries with developed financial systems and capital markets (Erić, et al., 2012), in addition to the traditional sources, have many more 
1988), pod investicijama u osnovne fondove prerađivačke industrije smatraju se ulaganja kapitala, pribavljenog iz sopstvenih i tudih izvora, u cilju dobijanja novih i povećanja vrednosti ili zamene postojećih investicionih dobara i kapaciteta. Prema domaćoj statističkoj evidenciji investiciona dobra mogu biti nova ili polovna, kupljena u zemlji i inostranstvu, nabavljena finansijskim lizingom i trampom, primljena kao kapitalni transfer $u$ naturi ili proizvedena za sopstvenu upotrebu. Investicije obuhvataju i ulaganja u nove kapacitete, kao i ulaganja u proširenje, modernizaciju i zamenu zastarelih i uništenih kapaciteta. Investicijama se ne obuhvataju sredstva utrošena za investiciono i redovno održavanje postojećih objekata (RZS, 2016). Ovakvo shvatanje se odnosi na realne investicije, tačnije finansijska sredstva koja se mogu investirati $u$ realne vrednosti ili fiksni kapital, pre svega, u materijalna i nematerijalna sredstva ili osnovne fondove. One ne uključuju finansijske investicije $\mathrm{u}$ hartije od vrednosti ili dugoročna finansijska ulaganja (Savić et al., 2015).

Investicije u osnovne fondove prerađivačke industrije predstavljaju deo BDP po rashodnom pristupu (RZS, 2016), koji u određenom periodu nije potrošen, već je namenjen za povećanje proizvodnje. Pored toga što su faktor rasta proizvodnje, one utiču na primenu znanja, tehnoloških inovacija i efikasnu upotrebu ostalih resursa, čime se menja postojeća struktura i nastaje nova struktura prerađivačke industrije (UNIDO, 2013). Dakle, investicije u osnovne fondove su $\mathrm{u}$ funkciji razvoja prerađivačke industrije, a viši nivo njenog razvoja znači i veću mogućnost izdvajanja kapitala za investicije. Ekonomski značaj investicija u osnovne fondove prerađivačke industrije proizilazi iz njihove uloge faktora održivog rasta proizvodnje i zaposlenosti, zbog čega su one važan instrument i sredstvo sprovođenja industrijske politike.

Težište ekonomske analize investicija u osnovne fondove su ekonomska efikasnost, strukturne promene i tehnološka modernizacija, zbog čega je značajna podela ovih investicija prema tehničkoj strukturi, karakteru izgradnje i izvorima finansiranja (Savić, et al., 2015).

Prema tehničkoj strukturi investicije se dele na ulaganja u građevinske objekte, mašine i opremu sa montažom i ostala ulaganja (RZS, 2016). Ova struktura investicija daje informacije o osnovnim elementima ulaganja i značajna je za ocenu ekonomske efikasnosti investicija. Prema karakteru izgradnje investicije se dele na investicije $u$ izgradnju novih kapaciteta, rekonstrukciju i održavanje, pri čemu ove investicije utiču na intenziviranje i racionalizaciju proizvodnje, ali ne i na proširenje kapaciteta, asortiman i tehnologiju proizvodnje.

U domaćoj statističkoj praksi investicije $\mathrm{u}$ osnovne fondove po izvorima finansiranja dele se na investicije iz sopstvenih i udruženih sredstava, kredita i sredstava ostalih fondova. Investicije iz sopstvenih sredstava obuhvataju sredstva investitora. Investicije iz udruženih sredstava obuhvataju sredstva domaćih i stranih investitora, kao i sredstva fizičkih lica i investitora, a na osnovu zajedničkog ulaganja. Investicije iz kredita obuhvataju bankarske i finansijske kredite i kredite ugovorene sa stranim firmama. Investicije iz ostalih fondova obuhvataju sredstva i/ili kredite dobijene od države i lokalne samouprave, ugovorene posredstvom banke ili direktno, koji se mogu vraćati ili ne (RZS, 2016).

$\mathrm{U}$ analizama, važna kategorija investicija su bruto investicije koje predstavljaju zbir svih izdataka za investicije $\mathrm{u}$ osnovne fondove, promene $\mathrm{u}$ vrednosti zaliha $\mathrm{i}$ promene $\mathrm{u}$ dragocenostima. Preciznije, bruto investicije $\mathrm{u}$ osnovne fondove se odnose na investicije $\mathrm{u}$ nove osnovne fondove, tj. ukupne investicije umanjene za dezinvestiranje ili vrednost polovnih osnovnih fondova, dok su ukupne investicije šira kategorija i obuhvataju investicije u nove i polovne osnovne fondove. Efikasnost investicija i korišćenja osnovnih fondova može se meriti na različite načine, a najčešće kapitalnim koeficijentom. Efikasnost bruto investicija se može iskazati bruto marginalnim kapitalnim koeficijentom koji pokazuje koliko je jedinica investicija potrebno da bi se ostvario prirast proizvodnje za jednu jedinicu. U bruto izrazu kapitalni koeficijent izračunava se kao količnik prirasta bruto investicija i BDP, dok je bruto koeficijent efikasnosti investicija količnik prirasta BDP i bruto investicija. 
possibilities to finance investment through the alternative sources (Gompers \& Lerner, 2001), such as venture capital (Hellmann \& Puri, 2000) and private investment funds (Inderst, 2013). The developed financial markets boost capital allocation and increase investment in the growing industries, and decrease it in the declining ones (Wurgler, 2000).

Regardless of whether perceived from a narrow (Sokoloff, 1984) or a broad perspective (Chen, et al., 1988), investment in the fixed assets of the manufacturing industry refers to investments of capital, acquired from internal or external sources, aimed at gaining new and increasing current value, or replacing the existing investment goods and capacities. According to the domestic statistical records, investment goods can be new or used, purchased in the country or abroad, acquired through financial leasing and barter, accepted as capital transfer in kind or produced for personal usage. Investment also covers investments into new capacities, as well as investments aimed at the expansion, modernization and replacement of outdated and destroyed capacities. Investment does not cover the assets spent for the purpose of investment and regular maintenance of the existing facilities (RZS, 2016). This definition refers to real investments, i.e. financial assets that can be invested into real values or fixed capital, primarily into tangible and intangible assets or fixed assets. This does not include financial investments into securities or longterm financial investments (Savić et al., 2015).

Investments into fixed assets of the manufacturing industry represent a segment of GDP calculated by the expenditure approach (RZS, 2016), which was not spent at a specific point, but, instead, dedicated to increasing production. In addition to being a factor of production growth, they influence the implementation of know-how, technological innovations and the efficient utilization of other resources, thereby changing the existing structure and creating the new structure of the manufacturing industry (UNIDO, 2013). Therefore, investments in fixed assets serve the function of the manufacturing industry development, with the higher level of its development implying the higher possibility of allocating capital for investment purposes. The economic significance of investments in fixed assets of the manufacturing industry arises from its role of a factor of sustainable growth of production and employment, which is why they are an important instrument and means of conducting industry policy.

The foundation of the economic analysis of investments in fixed assets are economic efficiency, structural changes and technological modernization, which is why it is significant to have these investments classified according to the technical structure, type of construction and sources of finance (Savić, et al., 2015).

According to technical structure, investments are divided into investments into buildings, machines and equipment including installation, and other investments (RZS, 2016). This structure of investments provides information about the basic elements of investment and is, thus, relevant for the assessment of economic efficiency of investment. According to the type of construction, investments are divided into investments into construction of new capacities, reconstruction, and maintenance, whereby such investments affect the intensification and rationalization of production, but not the expansion of capacities, assortment and technology of production.

In domestic statistical practice, investment in fixed assets is, according to sources of finance, divided into investment from net assets, pooled assets, loans and other assets. Investment from net assets includes the assets of investors. Investment from pooled assets includes assets of both domestic and foreign investments, as well as assets of natural persons and investors, in the form of joint ventures. Investment from loans includes bank and financial loans and loans arranged with foreign firms. Investment from other assets includes assets and/or loans granted by the state and local self-government, arranged via bank or directly, to be repaid or not (RZS, 2016).

An important category of investment in these analyses are gross investments, representing the sum of all expenditures for the purpose of investment into fixed assets, changes in the value of inventories and changes in valuable assets. More precisely, gross investments into fixed assets refer to investments into new fixed assets, i.e. total investments deduced 


\section{Investicije u osnovne fondove privrede Srbije}

U periodu 2001-2016. godine $u$ apsolutnim iznosima BDP Srbije povećan je sa 13,8 mlrd. na 34,1 mlrd. EUR, dok su bruto investicije $\mathrm{u}$ osnovne fondove privrede povećane sa 1,7 na 6 mlrd. EUR (Grafik 1). Najveći iznos investicija od 8,4 mlrd. EUR zabeležen je pre izbijanja svetske ekonomske i finansijske krize 2008. godine. Dinamika i odnos BDP i bruto investicija u periodu 2001-2016. godine pokazuju da i ako su investicije $\mathrm{u}$ apsolutnom iznosu povećane za 3,4 puta, a BDP za 2,5 puta, stopa investicija je morala biti veća, tj. raspodela BDP trebalo je da ide na račun finalne potrošnje, a u korist investicija u osnovne fondove, kako bi rast $\mathrm{BDP}$ bio znatno veći, a investicije osnova održivog rasta.
U periodu 2001-2016. došlo je do povećanja učešća bruto investicija u osnovne fondove privrede sa $12,9 \%$ na $17,8 \%$ u BDP (Grafik 2). Ipak, investiciona aktivnost je niska u odnosu na dostignuti nivo BDP po stanovniku (oko 4.830 EUR u 2016 godini). Posledice svetske ekonomske i finansiske krize posebno su uticale na inače nizak nivo stope investiranja i dinamiku investicija. Od 2008. godine stopa investiranja zabeležila je pad učešća u BDP za 7,5 procentnih poena. Posmatrajući dinamiku investiranja njena karakteristika je volatilnost. Sigurno da bi učešće bruto investicija $\mathrm{u}$ osnovne fondove bilo još manje, a volatilnost veća da nije bilo direktnih državnih podsticaja privatnim investicijama, poput subvencija za nova radna mesta $\mathrm{i}$ podsticaja za ulaganja u osnovne fondove.

Grafik 1. Dinamika i odnos BDP-a i investicija, u milionima EUR

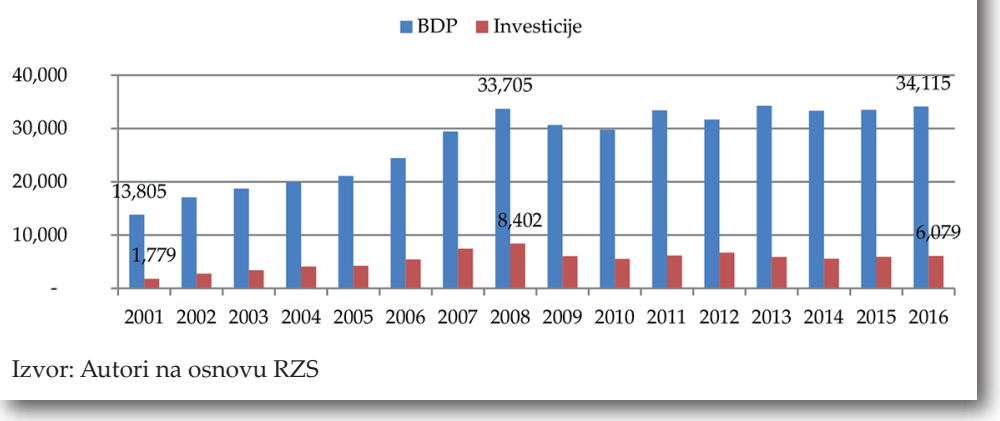

Grafik 2. Bruto investicije u osnovne fondove, učešće u BDP

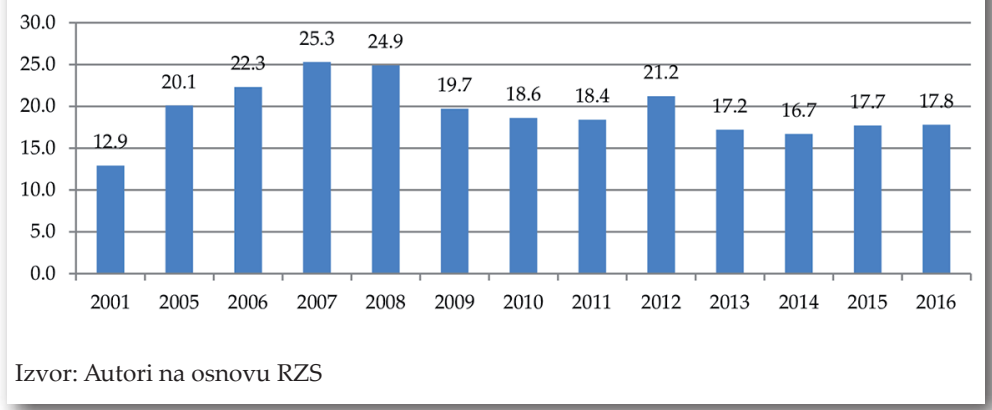


by disinvestments or the value of used fixed assets, whereas total investments are a broader category and include investments into both new and used fixed assets. The efficiency of investment into and usage of fixed assets can be measured in many different ways, most often by means of capital coefficients. The efficiency of gross investments can be measured in the form of the gross marginal capital coefficient, indicating how many investment units are required to achieve a production growth by one unit. The gross capital coefficient is calculated by dividing gross investment growth by GDP, whereas the gross investment efficiency coefficient is calculated by dividing GDP growth by gross investments.

\section{Investment in the Fixed Assets of the Serbian Economy}

In the period from 2001 to 2016, in absolute amounts, the GDP of Serbia has increased from EUR 13.8 billion to EUR 34.1 billion, while the gross investment in the fixed assets of the economy increased from EUR 1.7 billion to EUR 6 billion (Graph 1). The highest amount of investment, i.e. EUR 8.4 billion, was recorded before the outbreak of the global economic and financial crisis in 2008. The dynamics and relation between GDP and gross investment in the period from 2001 to 2016 suggest that, although investment in absolute amounts increased 3.4 times, and GDP 2.5 times, the investment rate ought to have been higher. In other words, the distribution of GDP should have been at the expense of final consumption, and in favor of investment in fixed assets, so that the GDP growth could end up substantially higher and investments the basis of sustainable growth.

In the period from 2001 to 2016, the share of gross investments into fixed assets in the economy rose from $12.9 \%$ to $17.8 \%$ of the GDP (Graph 2). Nonetheless, investment activity is low in relation to the reached level of GDP per capita (about 4,830 EUR in 2016). The effects of the global economic and financial crisis particularly influenced the already low investment level and the investment dynamic. Since 2008, the investment rate has recorded a drop in its share in the GDP by 7.5 percentage points. When it comes to investment dynamics, its characteristic is volatility. It is certain that the share of gross investments into fixed assets would be even lower and the volatility even higher if it were not for the direct state incentives for private investments, such as subsidies for new job openings and incentives for investments into fixed assets.

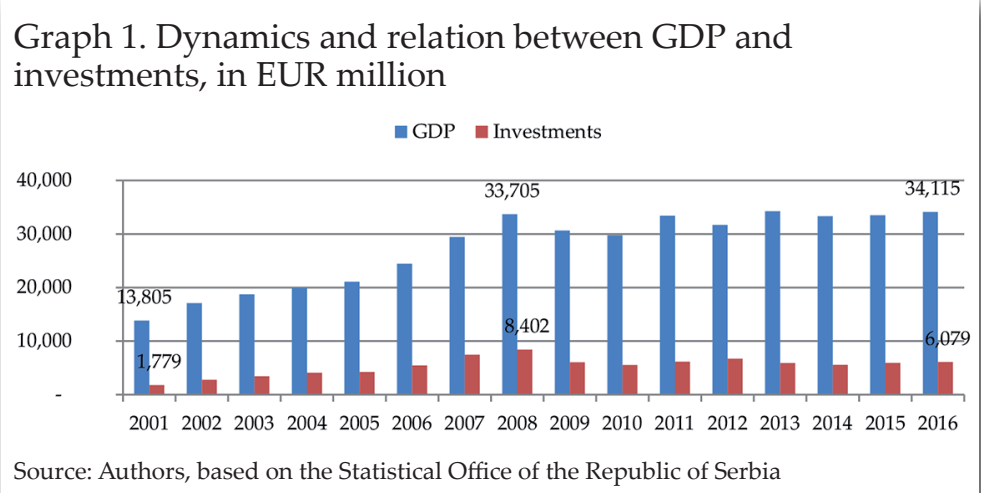

Graph 2. Gross investments in fixed assets, share in GDP

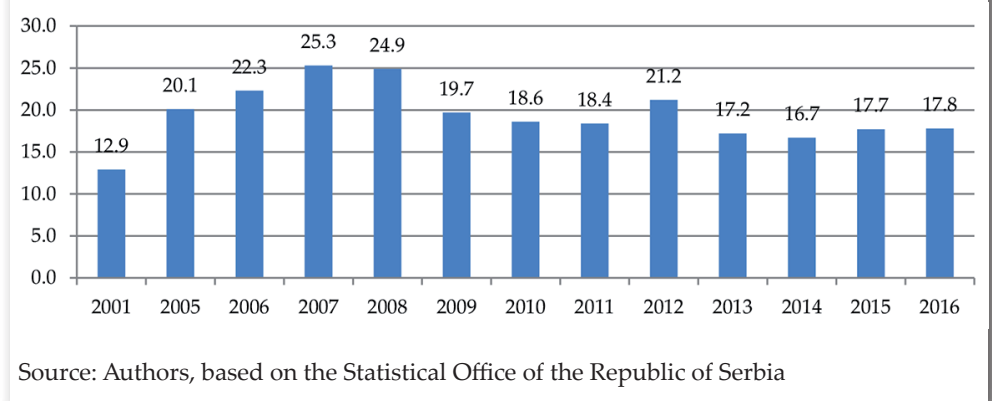


Da je investiciona aktivnost niska potvrđuje i komparacija stope investiranja sa državama iz okruženja, novim članicama EU i prosekom EU28 u periodu 2001-2015. godine (Tabela 1). Sve posmatrane zemlje usled posledica svetske ekonomske i finansijske krize od 2009. imaju pad učešća bruto investicija u osnovne fondove u BDP. U poređenju sa zemljama u okruženju Srbija ima najnižu stopu investiranja, a ukupne investicije manje su od 3\% do 7\%. U 2015. godini od posmatranih novih članica EU najveće učešće investicija u BDP imaju Češka (26,5\%) i Rumunija $(24,8 \%)$, a od zemalja koje nisu članice Albanija $(24,6 \%)$ i Makedonija (23,1\%), što pokazuje da one imaju nižu finalnu potrošnju i da se odriču skoro četvrtine BDP za investicije.
U periodu 2010-2015. godine $\mathrm{u}$ isplatama za investicije $\mathrm{u}$ osnovne fondove po izvorima finansiranja najveći deo poticao je iz sopstvenih sredstava 70,5\% (19,4 mlrd. EUR), dok su finansijska sredstava (bankarski i finansijski krediti) činila 17,7\% (4,9 mlrd. EUR) ukupno isplaćenih investicija (Tabela 2). Kretanje ova dva izvora, relativno i apsolutno, pokazuje da su sopstvena sredstava imala trend oscilacija, a da je dostupnost kredita posebno smanjena tokom 2013. i 2014. godine (nakon drugog talasa krize u EU), što je uticalo na smanjenje njihovog učešća $\mathrm{u}$ isplatama i na pad investicija. U 2015. godini je zabeležen apsolutan i relativan pad isplata iz sopstvenih sredstava, a rast isplata iz kredita. Kretanje isplata iz ostalih izvora i udruženih sredstava prati ovakve trendove. Učešće ostalih izvora prosečno je iznosilo godišnje 11,1\% (3 mlrd. EUR), dok je učešće udruženih sredstava bilo skromno $0,7 \%(0,2$ mlrd. EUR).
Tabela 1. Bruto investicije u osnovne fondove, učešće u BDP-u

\begin{tabular}{|l|c|c|c|c|c|c|c|c|c|}
\hline & 2001 & 2008 & 2009 & 2010 & 2011 & 2012 & 2013 & 2014 & 2015 \\
\hline EU 28 & 21,5 & 22,5 & 20,5 & 20,1 & 20,2 & 19,7 & 19,3 & 19,4 & 19,5 \\
\hline Češka R. & 30,5 & 29,0 & 27,1 & 26,9 & 26,5 & 25,9 & 25,1 & 25,1 & 26,5 \\
\hline Rumunija & 20,9 & 38,4 & 26,0 & 25,9 & 27,1 & 27,3 & 24,7 & 24,3 & 24,8 \\
\hline Slovačka & 30,2 & 25,5 & 21,7 & 22,1 & 24,0 & 21,2 & 20,7 & 20,4 & 23,0 \\
\hline Mađarska & 24,8 & 23,3 & 22,8 & 20,3 & 19,8 & 19,4 & 20,9 & 21,8 & 21,7 \\
\hline Bugarska & 19,4 & 33,0 & 27,9 & 22,2 & 20,9 & 21,3 & 21,1 & 21,1 & 21,0 \\
\hline Poljska & 20,5 & 23,1 & 21,4 & 20,3 & 20,7 & 19,8 & 18,8 & 19,7 & 20,1 \\
\hline Slovenija & 26,4 & 29,6 & 24,3 & 21,3 & 20,2 & 19,3 & 20,0 & 19,6 & 19,5 \\
\hline Hrvatska & 20,4 & 28,1 & 25,2 & 21,3 & 20,3 & 19,6 & 19,8 & 19,4 & 19,8 \\
\hline Albanija & 36,7 & 33,9 & 32,7 & 28,4 & 29,4 & 26,5 & 26,1 & 24,2 & 24,6 \\
\hline Makedonija & 22,0 & 25,8 & 24,6 & 23,1 & 23,5 & 23,4 & 23,7 & 23,4 & 23,1 \\
\hline Crna Gora & $/$ & $/$ & $/$ & 21,6 & 19,5 & 19,8 & 20,2 & 19,0 & 20,3 \\
\hline Srbija & 12,9 & 24,9 & 19,7 & 18,6 & 18,4 & 21,2 & 17,2 & 16,7 & 17,7 \\
\hline
\end{tabular}

Tabela 2. Isplate za investicije $\mathrm{u}$ osnovne fondove, po izvorima finansiranja

\begin{tabular}{|l|r|r|r|r|r|r|r|}
\hline Izvori finansiranja & 2010. & 2011. & 2012. & 2013. & 2014. & 2015. & $\begin{array}{c}\text { Prosek } \\
2010-2015 .\end{array}$ \\
\hline & \multicolumn{7}{|c|}{$\mathrm{u} \%$} \\
\hline Iz sopstvenih sredstava & 71,7 & 64,0 & 68,0 & 77,2 & 74,7 & 67,3 & 70,5 \\
\hline Iz udruženih sredstava & 0,5 & 0,4 & 1,7 & 0,4 & 0,5 & 0,8 & 0,7 \\
\hline Iz finansijskih sredstava & 18,3 & 20,1 & 19,9 & 15,0 & 12,5 & 20,7 & 17,7 \\
\hline Iz ostalih fondova & 9,5 & 15,5 & 10,5 & 7,4 & 12,3 & 11,2 & 11,1 \\
\hline Ukupno & 100,0 & 100,0 & 100,0 & 100,0 & 100,0 & 100,0 & 100,0 \\
\hline Izvori finansiranja & \multicolumn{7}{|c|}{ milioni EUR } \\
\hline Iz sopstvenih sredstava & 3.071 & 3.202 & 3.394 & 3.524 & 3.194 & 3.064 & 19.450 \\
\hline Iz udruženih sredstava & 22 & 22 & 83 & 18 & 21 & 38 & 204 \\
\hline Iz finansijskih sredstava & 82 & 1.005 & 992 & 686 & 537 & 941 & 4.942 \\
\hline Iz ostalih fondova & 408 & 776 & 524 & 336 & 526 & 507 & 3.077 \\
\hline Ukupno & 4.282 & 5.006 & 4.993 & 4.563 & 4.278 & 4.550 & 27.672 \\
\hline
\end{tabular}

Izvor: Autori na osnovu RZS 
Low investment activity is further confirmed by the comparison of the investment rate with those of the neighbouring states, the new EU members and the EU-28 average from 2001 to 2015 (Table 1). All observed countries have a decreased share of gross investments into the fixed assets in the GDP, due to the effects of the 2009 global economic and financial crisis. In comparison to its neighbouring countries, Serbia has the lowest investment rate, its gross investments being lower by 3\% to 7\%. In 2015, out of the observed new EU members, the highest share of investments into the GDP was seen in the Czech Republic (26.5\%) and Romania $(24.8 \%)$, while in the non-member states the highest share was observed in Albania (24.6\%) and the Republic of Macedonia (23.1\%), which shows that they have a lower final consumption and that they set aside nearly a quarter of their GDP for investments.
In the period from 2010 to 2015, when it comes to payments for investments into fixed assets according to sources of finance, the largest part came from net assets, i.e. 70.5\% (19.4 billion EUR), whereas financial assets (bank and financial loans) accounted for 17.7\% (4.9 billion EUR) of the total paid investments (Table 2). The movements of these two sources, in both relative and absolute terms, suggest that the net assets have recorded a trend of oscillations, while the accessibility of loans particularly decreased in the course of 2013 and 2014 (after the second wave of crisis in the EU), which has contributed to the reduction of their share in payments and a drop in investments. In 2015 there was a relative and absolute decline of payments from net assets, accompanied by a growth of payments from loans. The movements of payments from other sources and pooled assets followed such trends as well. The share of other sources on average amounted to $11.1 \%$ (3 billion EUR) annually, whereas the share of pooled assets stayed at the modest level of $0.7 \%(0.2$ billion EUR).
Table 1. Gross investments in fixed assets, share in GDP

\begin{tabular}{|l|c|c|c|c|c|c|c|c|c|}
\hline & 2001 & 2008 & 2009 & 2010 & 2011 & 2012 & 2013 & 2014 & 2015 \\
\hline EU 28 & 21.5 & 22.5 & 20.5 & 20.1 & 20.2 & 19.7 & 19.3 & 19.4 & 19.5 \\
\hline Czech R. & 30.5 & 29.0 & 27.1 & 26.9 & 26.5 & 25.9 & 25.1 & 25.1 & 26.5 \\
\hline Romania & 20.9 & 38.4 & 26.0 & 25.9 & 27.1 & 27.3 & 24.7 & 24.3 & 24.8 \\
\hline Slovakia & 30.2 & 25.5 & 21.7 & 22.1 & 24.0 & 21.2 & 20.7 & 20.4 & 23.0 \\
\hline Hungary & 24.8 & 23.3 & 22.8 & 20.3 & 19.8 & 19.4 & 20.9 & 21.8 & 21.7 \\
\hline Bulgaria & 19.4 & 33.0 & 27.9 & 22.2 & 20.9 & 21.3 & 21.1 & 21.1 & 21.0 \\
\hline Poland & 20.5 & 23.1 & 21.4 & 20.3 & 20.7 & 19.8 & 18.8 & 19.7 & 20.1 \\
\hline Slovenia & 26.4 & 29.6 & 24.3 & 21.3 & 20.2 & 19.3 & 20.0 & 19.6 & 19.5 \\
\hline Croatia & 20.4 & 28.1 & 25.2 & 21.3 & 20.3 & 19.6 & 19.8 & 19.4 & 19.8 \\
\hline Albania & 36.7 & 33.9 & 32.7 & 28.4 & 29.4 & 26.5 & 26.1 & 24.2 & 24.6 \\
\hline Macedonia & 22.0 & 25.8 & 24.6 & 23.1 & 23.5 & 23.4 & 23.7 & 23.4 & 23.1 \\
\hline Montenegro & $/$ & $/$ & $/$ & 21.6 & 19.5 & 19.8 & 20.2 & 19.0 & 20.3 \\
\hline Serbia & 12.9 & 24.9 & 19.7 & 18.6 & 18.4 & 21.2 & 17.2 & 16.7 & 17.7 \\
\hline
\end{tabular}

Table 2. Payments for investments in fixed assets, per sources of finance

\begin{tabular}{|l|r|r|r|r|r|r|r|r|}
\hline Sources of finance & 2010 & 2011 & 2012 & 2013 & 2014 & 2015 & $\begin{array}{c}\text { On average } \\
2010-2015\end{array}$ \\
\hline & \multicolumn{7}{|c|}{ in \% } \\
\hline From net assets & 71.7 & 64.0 & 68.0 & 77.2 & 74.7 & 67.3 & 70.5 \\
\hline From pooled assets & 0.5 & 0.4 & 1.7 & 0.4 & 0.5 & 0.8 & 0.7 \\
\hline From financial assets & 18.3 & 20.1 & 19.9 & 15.0 & 12.5 & 20.7 & 17.7 \\
\hline From other assets & 9.5 & 15.5 & 10.5 & 7.4 & 12.3 & 11.2 & 11.1 \\
\hline Total & 100.0 & 100.0 & 100.0 & 100.0 & 100.0 & 100.0 & 100.0 \\
\hline Sources of finance & \multicolumn{7}{|c|}{ In EUR million } \\
\hline From net assets & 3,071 & 3,202 & 3,394 & 3,524 & 3,194 & 3,064 & 19,450 \\
\hline From pooled assets & 22 & 22 & 83 & 18 & 21 & 38 & 204 \\
\hline From financial assets & 82 & 1,005 & 992 & 686 & 537 & 941 & 4,942 \\
\hline From other assets & 408 & 776 & 524 & 336 & 526 & 507 & 3,077 \\
\hline Total & 4,282 & 5,006 & 4,993 & 4,563 & 4,278 & 4,550 & 27,672 \\
\hline
\end{tabular}

Source: Authors, based on Eurostat and the Statistical Office of the Republic of Serbia 


\section{Investicije u osnovne fondove prerađivačke industrije Srbije}

U periodu 2002-2015. godine $\mathrm{u}$ apsolutnim iznosima bruto investicije $\mathrm{u}$ osnovne fondove prerađivačke industrije Srbije povećane sa 313,5 mil. EUR na 991 mil. EUR (Grafik 3). U pred kriznom periodu iznosi bruto investicija konstantno su rasli do 2008. godine kada njihov iznos dostiže oko 1,7 mlrd. EUR. Posle izbijanja krize iznosi bruto investicija u osnovne fondove Prerađivačke industrije variraju od 963 mil. do 2 mlrd. EUR. Najveći iznos investicija od $2 \mathrm{mlrd}$. EUR zabeležen je 2012. godini usled ulaganja u Proizvodnju motornih vozila od strane „FIAT" i države Srbije.

Grafik 3. Dinamika bruto investicija u osnovne fondove prerađivačke industrije, u hiljadama EUR

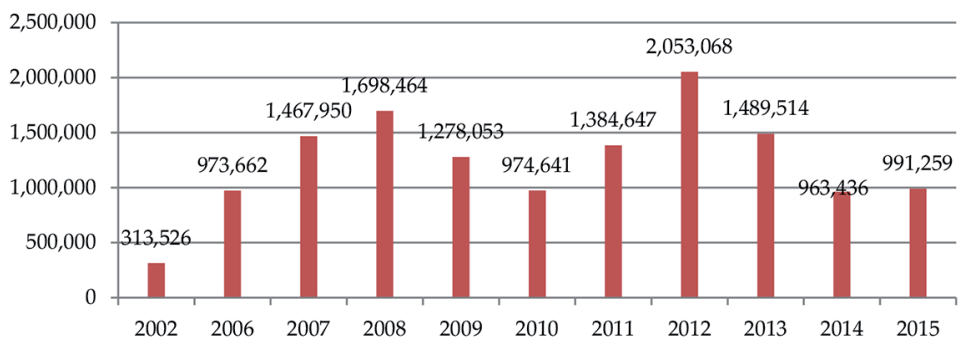

Izvor: Autori na osnovu RZS

U periodu 2006-2010. godine učešća bruto $(1,3)$ (RZS i Eurostat).

Ukoliko se uporedi učešće prerađivačke industrije $\mathrm{u}$ bruto investicijama privrede Srbije moglo bi se oceniti da je ono na zavidnom nivou u odnosu na prosek EU28 i posmatrane nove članice EU, kako u pred kriznom, tako i $\mathrm{u}$ post kriznom periodu (Tabela 3 ). Srbija je u periodu 2010-2014. godine sa učešćem od 26,5\% imala niže učešće samo od Rumunije (40\%) i Mađarske (28\%). Ipak, kolika i kakva je investiciona aktivnost ne pokazuju samo stope investiranja, već i apsolutni iznosi investicija. U periodu 2010-2014. godina u prerađivačkoj industriji Srbije bruto investicije iznose oko 1,4 mlrd. EUR, dok su one znatno veće u Rumuniji $(14,1)$, Poljskoj $(12,9)$, Češkoj $(8,9)$, Mađarskoj $(5,7)$, Slovačkoj $(3,7)$, a na sličnom nivou u Sloveniji $(1,6)$ i Bugarskoj investicija u osnovne fondove prerađivačke industrije u odnosu na investicije privrede bilo je prilično konstantno i kretalo se od $21 \%$ do $22 \%$ (Grafik 4). Od 2011. godine došlo je do povećanja ovog učešća sa $25,6 \%$ na $34,6 \%$ u 2012. godini i $30,2 \%$ u 2013. godini stopa investiranja $\mathrm{u}$ prerađivačkoj industriji $\mathrm{u}$ 2014. godini ponovo je na višegodišnjem proseku pred kriznog perioda i iznosi oko $21 \%$.

Posmatrano u odnosu na učešće u BDP od 2008. godine došlo je do pada učešća bruto investicija prerađivačke industrije sa $5 \%$ na $2,9 \%$, izuzev 2012. godine kada su investicije Prerađivačke industrije iznosile 6,5\% BDP.
Tabela 3. Učešće prerađivačke industrije u bruto investicijama privrede

\begin{tabular}{|c|c|c|c|c|c|c|c|c|c|c|}
\hline & 2002. & 2006. & 2007. & 2008. & 2009. & 2010. & 2011. & 2012. & 2013. & 2014. \\
\hline $\mathrm{U} 28$ & 18,2 & 16,6 & 16,0 & 15,8 & 14,9 & 14,7 & 16,3 & 16,6 & 16,5 & 16,7 \\
\hline Bugarska & 21,4 & 15,8 & 15,2 & 15,5 & 11,8 & 11,6 & 14,9 & 15,2 & 15,1 & 15,2 \\
\hline Češka R. & 24,5 & 24,0 & 24,8 & 22,8 & 19,1 & 17,7 & 20,5 & 22,4 & 23,3 & 24,5 \\
\hline Mađarska & 19,6 & 21,0 & 23,9 & 22,5 & 19,7 & 22,1 & 28,6 & 31,1 & 30,4 & 26,9 \\
\hline Poljska & 19,7 & 21,5 & 21,0 & 20,1 & 18,0 & 15,8 & 16,1 & 16,2 & 17,3 & 18,4 \\
\hline Rumunija & 46,2 & 48,4 & 40,2 & 36,6 & 41,4 & 34,2 & 36,1 & 42,1 & 43,5 & 42,0 \\
\hline Slovenija & 21,8 & 21,0 & 18,4 & 17,7 & 17,0 & 18,7 & 22,2 & 22,5 & 22,6 & 23,4 \\
\hline Slovačka & 28,0 & 29,5 & 23,9 & 25,8 & 19,9 & 19,1 & 27,6 & 25,0 & 22,5 & 24,3 \\
\hline Srbija & 15,8 & 21,5 & 21,9 & 22,1 & 22,2 & 20,8 & 25,6 & 34,6 & 30,2 & 21,1 \\
\hline
\end{tabular}

U periodu 2010-2015. najveći iznosi bruto i novih investicija posmatrano po oblastima prerađivačke industrije, investiran je $u$ proizvodnju motornih vozila, proizvodnju koksa i derivata nafte i proizvodnju prehrambenih 


\section{Investment in the Fixed Assets of the Manufacturing Industry of Serbia}

In the period from 2002 to 2015, in absolute amounts the gross investments in fixed assets of the manufacturing industry of Serbia increased from 313.5 million EUR to 991 million EUR (Graph 3). Before the crisis, the amounts of gross investments were steadily increasing, up until 2008 when they reached about 1.7 billion EUR. After the crisis broke out, the amounts of gross investments into fixed assets of the manufacturing industry ranged from 963 million EUR to 2 billion EUR. The largest amount of investments, i.e. 2 billion EUR, was recorded in 2012, as a result of the investment into the manufacture of motor vehicles by FIAT and the Serbian Government.

Graph 3. Dynamics of gross investments in the fixed assets of the manufacturing industry, in EUR thousand

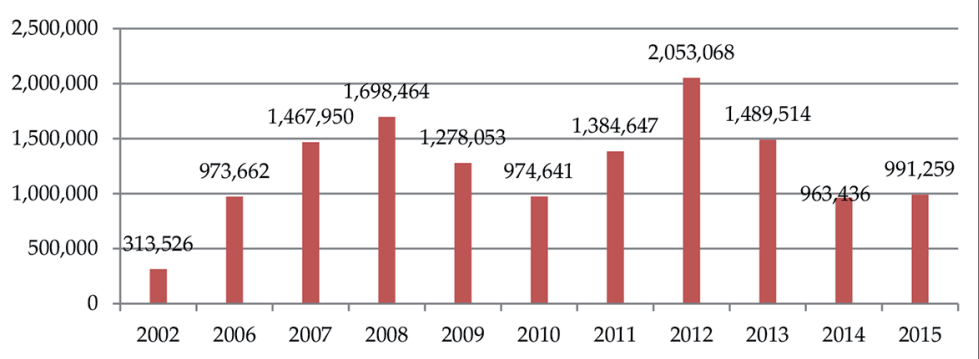

Source: Authors, based on the Statistical Office of the Republic of Serbia

In the period from 2006 to 2010 the share of gross investments into fixed assets of the manufacturing industry in relation to the investments into economy remained rather steady, ranging from $21 \%$ to 22\% (Graph 4). Since 2011 there has been an increase in this share, from $25.6 \%$ to $34.6 \%$ in 2012 and $30.2 \%$ in 2013. In 2014 the rate of investment in the manufacturing industry reached its pre-crisis average, amounting to about $21 \%$. Since 2008 the share of gross investments in the manufacturing industry in GDP declined from $5 \%$ to $2.9 \%$, except in 2012 when the investments in the manufacturing industry accounted for $6.5 \%$ of GDP.
Having compared the share of the manufacturing industry in the gross investments into the economy of Serbia, we have assessed it as rather satisfactory in relation to the average of EU28 and the observed new EU members, both before and after the crisis (Table 3). In the period from 2010 to 2014, with its share of $26.5 \%$, Serbia recorded a share lower only than in Romania (40\%) and Hungary $(28 \%)$. Nevertheless, the scope and quality of investment activities is not only indicated by the investment rates, butalso by the absolute amounts of the concerned investments. In the period from 2010 to 2014 the gross investments in the manufacturing industry of Serbia amounted to about 1.4 billion EUR, whereas they are substantially higher in Romania (14.1), Poland (12.9), Czech Republic (8.9), Hungary (5.7), Slovakia (3.7), and at the similar level in Slovenia (1.6) and Bulgaria $(1,3)$ (RZS and Eurostat).
Table 3. Share of the manufacturing industry in the gross investments into the economy

\begin{tabular}{|l|c|c|c|c|c|c|c|c|c|c|}
\hline & 2002 & 2006 & 2007 & 2008 & 2009 & 2010 & 2011 & 2012 & 2013 & 2014 \\
\hline U28 & 18.2 & 16.6 & 16.0 & 15.8 & 14.9 & 14.7 & 16.3 & 16.6 & 16.5 & 16.7 \\
\hline Bulgaria & 21.4 & 15.8 & 15.2 & 15.5 & 11.8 & 11.6 & 14.9 & 15.2 & 15.1 & 15.2 \\
\hline Czech R. & 24.5 & 24.0 & 24.8 & 22.8 & 19.1 & 17.7 & 20.5 & 22.4 & 23.3 & 24.5 \\
\hline Hyngary & 19.6 & 21.0 & 23.9 & 22.5 & 19.7 & 22.1 & 28.6 & 31.1 & 30.4 & 26.9 \\
\hline Poland & 19.7 & 21.5 & 21.0 & 20.1 & 18.0 & 15.8 & 16.1 & 16.2 & 17.3 & 18.4 \\
\hline Romania & 46.2 & 48.4 & 40.2 & 36.6 & 41.4 & 34.2 & 36.1 & 42.1 & 43.5 & 42.0 \\
\hline Slovenia & 21.8 & 21.0 & 18.4 & 17.7 & 17.0 & 18.7 & 22.2 & 22.5 & 22.6 & 23.4 \\
\hline Slovakia & 28.0 & 29.5 & 23.9 & 25.8 & 19.9 & 19.1 & 27.6 & 25.0 & 22.5 & 24.3 \\
\hline Serbia & 15.8 & 21.5 & 21.9 & 22.1 & 22.2 & 20.8 & 25.6 & 34.6 & 30.2 & 21.1 \\
\hline
\end{tabular}

Source: Authors, based on Eurostat and the Statistical Office of the Republic of Serbia

In the period from 2010 to 2015, the highest amounts of gross and new investments, 
proizvoda (Tabela 4). U ove tri oblasti investirano je oko 50\% ukupnih investicija prerađivačkog sektora, koliko je investirano u ostalu 21 oblast. Kao posledica većih investicija, ove tri oblasti ostvarile su i najveći nivo proizvodne specijalizacije i izvoza. Takođe, posmatrano prema tehnološkoj intenzivnosti proizvodnje najveći deo investicija, izuzev onih u oblasti proizvodnje motornih vozila, realizovan je oblastima niske i srednje niske tehnološke intenzivnosti proizvodnje, a time i niskog nivoa dodate vrednosti i produktivnosti. To su oblasti proizvodnje koje su intenzivne radom i prirodnim resursima, a što se odražava na konkurentnost i kvalitet izvoza prerađivačke industrije Srbije.
Analizirajući ostvarene iznose bruto i novih investicija $u$ osnovne fondove privrede i prerađivačke industrije Srbije po tehničkoj strukturi može se oceniti da u usmerenosti investicija dominira oprema (Tabela 5). Najveća namena bruto investicija prerađivačke industrije po tehničkoj strukturi bila je u opremu oko $63 \%$, zgrade, ostale građevinske objekte i radove oko $33 \%$ i ostalo $4 \%$. Slična situacija je ako se posmatraju nove investicije po tehničkoj strukturi gde je skoro dve trećine sredstava investirano u opremu, a jedna trećina u zgrade, građevinske objekte i radove i ostalo. Veće učešće investicija u opremu, posebno ukoliko se efikasnije efektuira, značajno je zbog povećavanja proizvodne sposobnosti Prerađivačkog sektora.

Tabela 4. Bruto i nove investicije po oblastima prerađivačke industrije, 2010-2015. godina milioni EUR

\begin{tabular}{|l|r|r|}
\hline Oblast & Bruto & \multicolumn{1}{|c|}{ Nove } \\
\hline Proizvodnja motornih vozila & 1.386 & 1.349 \\
\hline Proizvodnja prehrambenih proizvoda & 1.256 & 1.063 \\
\hline Proizvodnja koksa i derivata nafte & 1.281 & 1.277 \\
\hline Proizvodnja proizvoda od gume i plastike & 632 & 597 \\
\hline Proizvodnja metalnih proizvoda & 456 & 403 \\
\hline Proizvodnja hemikalija i hemijskih proizvoda & 415 & 370 \\
\hline Proizvodnja pića & 271 & 246 \\
\hline Proizvodnja osnovnih metala & 244 & 231 \\
\hline Proizvodnja nemetalnih minerala & 239 & 221 \\
\hline Proizvodnja električne opreme & 234 & 217 \\
\hline Ostale proizvodne oblasti & 1.677 & 1.251 \\
\hline Prerađivačka industrija ukupno & 7.856 & 7.225 \\
\hline Izvor: Autori na osnovu RZS & \multicolumn{2}{|l}{} \\
\hline
\end{tabular}

Tabela 5. Ostvarene investicije u osnovne fondove po tehničkoj strukturi, 2010-2015. godina u milionima EUR

\begin{tabular}{|l|r|r|r|r|}
\hline & Ukupno & $\begin{array}{c}\text { Zgrade i ostale } \\
\text { građevine }\end{array}$ & Oprema & Ostalo \\
\hline & \multicolumn{4}{|c|}{ Bruto } \\
\hline Privreda & 30.218 & 12.470 & 15.197 & 2.181 \\
\hline Učešće, \% & 100,0 & 41,3 & 51,5 & 7,2 \\
\hline Prerađivačka industrija & 7.856 & 2.586 & 4.920 & 310 \\
\hline Učešće, \% & 100,0 & 32,9 & 63,1 & 4,0 \\
\hline & \multicolumn{5}{|c|}{ Nove } \\
\hline Privreda & 27.074 & 11.176 & 14.661 & 1.658 \\
\hline Učešće, \% & 100,0 & 39,7 & 54,2 & 6,1 \\
\hline Prerađivačka industrija & 7.225 & 2.297 & 4.784 & 238 \\
\hline Učešće, \% & 100,0 & 30,5 & 66,2 & 3,3 \\
\hline Izvor: Autori na osnovu RZS & &
\end{tabular}


observed per branches of the manufacturing industry, were invested into the manufacture of motor vehicles, manufacture of coke and oil derivatives, and manufacture of food products (Table 4). These three branches attracted about $50 \%$ of the total investments into the manufacturing industry, as was invested in the remaining 21 branches. As a result of higher investments, these three branches achieved the highest level of production specialization and export. Moreover, according to the technological intensity of production, the largest part of investments, except for those in the field of motor vehicles manufacturing, was attracted by the branches of low and medium technological intensity of production, consequently the branches of low value added and low productivity. These are work intensive manufacturing branches, relying on natural resources, which is reflected in the competitiveness and quality of export of the manufacturing industry of Serbia.
Having analyzed the achieved amounts of gross and new investments into fixed assets of the economy and the manufacturing industry of Serbia according to technical structure, we have assessed that equipment is the predominant investment target (Table 5). The major purpose of gross investments in the manufacturing industry according to technical structure was equipment, amounting to about $63 \%$, followed by buildings, other premises and construction works with about 33\%, and other with $4 \%$. Similar situation can be detected if we observe new investments per technical structure, with almost two thirds of assets invested into equipment, and one third into buildings, premises, construction works, and other. A higher share of investments into equipment, especially if achieved more efficiently, is significant for the purpose of boosting the production capacities of the manufacturing industry.

Table 4. Gross and new investments per

manufacturing industry branches, 2010-2015, in EUR million

\begin{tabular}{|l|r|r|}
\hline Branch & Gross & New \\
\hline Manufacture of motor vehicles & 1,386 & 1,349 \\
\hline Manufacture of food products & 1,256 & 1,063 \\
\hline Manufacture of coke and oil derivatives & 1,281 & 1,277 \\
\hline Manufacture of rubber and plastic products & 632 & 597 \\
\hline Manufacture of metal products & 456 & 403 \\
\hline Manufacture of chemicals and chemical products & 415 & 370 \\
\hline Manufacture of beverages & 271 & 246 \\
\hline Manufacture of basic metals & 244 & 231 \\
\hline Manufacture of non-metal minerals & 239 & 221 \\
\hline Manufacture of electrical equipment & 234 & 217 \\
\hline Other manufacturing branches & 1,677 & 1,251 \\
\hline Manufacturing industry in total & 7,856 & 7,225 \\
\hline Source: Authors, based on the Statistical Office of the Republic of Serbia
\end{tabular}

Table 5. Realized investments in fixed assets per technical structure, 2010-2015, in EUR million

\begin{tabular}{|l|r|r|r|r|}
\hline & Total & $\begin{array}{c}\text { Buildings and } \\
\text { other premises }\end{array}$ & Equipment & Other \\
\hline & \multicolumn{4}{|c|}{ Gross } \\
\hline Economy & 30,218 & 12,470 & 15,197 & 2,181 \\
\hline Share, \% & 100.0 & 41.3 & 51.5 & 7.2 \\
\hline Manufacturing industry & 7,856 & 2,586 & 4,920 & 310 \\
\hline Share, \% & 100.0 & 32.9 & 63.1 & 4.0 \\
\hline & \multicolumn{5}{|c}{ New } \\
\hline Economy & 27,074 & 11,176 & 14.661 & 1.658 \\
\hline Share, \% & 100.0 & 39.7 & 54.2 & 6.1 \\
\hline Manufacturing industry & 7,225 & 2,297 & 4,784 & 238 \\
\hline Share, \% & 100.0 & 30.5 & 66.2 & 3.3 \\
\hline
\end{tabular}


U Tabeli 6 prikazane su isplate za investicije $\mathrm{u}$ osnovne fondove $\mathrm{u}$ sektoru i oblastima prerađivačke industrije Srbije $u$ periodu 2010-2015. godine. Bez obzira na vreme izgradnje ili nabavke osnovnih fondova, isplatama za investicije u sektoru i oblastima prerađivačke industrije obuhvaćena su sva novčana ulaganja $\mathrm{u}$ toku godine $\mathrm{u}$ kojoj su isplate stvarno izvršene, kao i otplate kredita i finansijskog lizinga. Posmatrano po oblastima prerađivačke industrije, slično kao i kod iznosa bruto i novih investicija, najveći iznosi isplata realizovani su u proizvodnji koksa i derivata nafte, proizvodnji prehrambenih proizvoda i proizvodnji motornih vozila. U ove tri oblasti isplaćeno je oko 50\% ukupnih isplata za investicije prerađivačkog sektora.
Zbog niskog BDP i skromnih akumulativnih mogućnosti za potrebe finansiranja razvoja privrede odnosno za modernizaciju i prerađivačke industrije korišćene su i SDI. U Tabeli 7 prikazana su neto povećanja finansijskih obaveza stranih direktnih ulaganja u periodu 2010-2015. godina. U ovom periodu došlo je do poboljšana je strukture SDI i povećanja ulaganja u sektor prerađivačke industrije (oko 31\%) odnosno, sektor razmenljivih dobara. Najveći deo SDI, pre svetske ekonomske i finansijske krize bio je usmeren $\mathrm{u}$ usluge. Posmatrano po oblastima prerađivačke industrije, slično kao i kod iznosa bruto i investicija, najveći priliv ostvaren je u proizvodnji prehrambenih proizvoda i pića, proizvodnji motornih vozila, proizvodnji proizvoda od gume i plastike i proizvodnji hemijskih proizvoda.

Tabela 6. Isplate za investicije u sektoru i oblastima prerađivačke industrije, 20102015. godina, u milionima EUR

\begin{tabular}{|c|c|c|c|c|c|c|c|}
\hline Oblast & 2010. & 2011. & 2012. & 2013. & 2014. & 2015. & Ukupno \\
\hline Proizvodnja koksa i derivata nafte & 174,5 & 320,6 & 344,7 & 451,1 & 6,0 & 4,8 & 1.302 \\
\hline Proizvodnja prehrambenih proizvoda & 191,4 & 205,2 & 210,8 & 226,4 & 158,7 & 175,1 & 1.168 \\
\hline Proizvodnja motornih vozila & 67,1 & 233,9 & 262,1 & 306,8 & 139, & 73,4 & 1.083 \\
\hline Proizvodnja proiz. od gume i plastike & 56,8 & 58,5 & 66,6 & 104,1 & 151,2 & 137,2 & 574 \\
\hline Proizvodnja metalnih proizvoda & 57,7 & 76,1 & 73,8 & 65,4 & 61,3 & 83,3 & 418 \\
\hline Proizvodnja hemikalija i hem. proizvoda & 32,2 & 46,9 & 72,3 & 79,3 & 60,6 & 66,6 & 358 \\
\hline Proizvodnja pića & 54,5 & 36,5 & 33,3 & 36,6 & 31,6 & 39,6 & 232 \\
\hline Proizvodnja nemetalnih minerala & 45,1 & 35,7 & 48,6 & 40,3 & 25,9 & 29,1 & 225 \\
\hline Proizvodnja osnovnih metala & 36,3 & 70,1 & 38,1 & 17,9 & 26,5 & 34,9 & 224 \\
\hline Proizvodnja papira i proizvoda od papira & 20,9 & 15,5 & 33,0 & 65,8 & 32,3 & 42,1 & 210 \\
\hline Ostale proizvodne oblasti & 169,6 & 159,5 & 253,5 & 229,2 & 242,7 & 251,8 & 1.306 \\
\hline Prerađivačka industrija & 906 & 1.259 & 1.437 & 1.623 & 936 & 938 & 7.098 \\
\hline
\end{tabular}

Tabela 7. SDI po oblastima prerađivačke industrije u periodu 2010 - 2016. godina, u milionima EUR

\begin{tabular}{|l|r|r|r|r|r|r|r|}
\hline & \multicolumn{1}{|c|}{2010.} & \multicolumn{1}{|c|}{2011.} & 2012. & 2013. & 2014. & 2015. & Ukupno \\
\hline Privreda & 1.278 & 3.544 & 1.008 & 1.547 & 1.500 & 2.114 & 10.994 \\
\hline Prerađivačka industrija & 329,4 & 631,1 & 521,2 & 679,2 & 535,2 & 721,1 & 3.417 \\
\hline $\begin{array}{l}\text { Proizvodnja prehrambenih proizvoda } \\
\text { pića i duvanskih proizvoda }\end{array}$ & 38,0 & 249,3 & 157,8 & 166,2 & 108,5 & 122,9 & 842,8 \\
\hline Proizvodnja proiz. od gume i plastike & 67,2 & 93,2 & 151,1 & 186,8 & 172,6 & 141,9 & 812,9 \\
\hline Proizvodnja motornih vozila & 10,5 & 70,6 & 14,9 & 31,2 & 37,8 & 140,5 & 305,5 \\
\hline $\begin{array}{l}\text { Proizvodnja hemikalija i hemijskih } \\
\text { proizvoda }\end{array}$ & 38,2 & 51,2 & 31,2 & 45,8 & 46,3 & 66,6 & 279,3 \\
\hline
\end{tabular}


Table 6 shows the payments for investments into fixed assets in the overall manufacturing industry of Serbia and its branches in the period from 2010 to 2015. Regardless of the date of construction or acquisition of fixed assets, the payments for investments in the manufacturing industry and its branches covers all monetary investments in the course of a year, in respect of which the payments were actually effected, along with the repayments of loans and financial leasing. Broken down by branches of the manufacturing industry, similarly to the amounts of gross and new investments, the highest amounts of payments were achieved in the manufacture of coke and oil derivatives, manufacture of food products, and manufacture of motor vehicles. These three braches accounted for about $50 \%$ of the total payments for investments in the manufacturing industry.
Due to the low GDP and modest accumulation capacity, FDI was also used for the purpose of financing economic development, i.e. the modernization of the manufacturing industry. Table 7 shows the net increases of financial liabilities in respect of the FDI in the period from 2010 to 2015. In this period the FDI structure improved and the investments into the manufacturing industry, i.e. the sector of exchangeable goods increased (by about $31 \%$ ). Before the global economic and financial crisis, the major part of the FDI was directed into services. Broken down by branches of the manufacturing industry, similarly to the amounts of gross and new investments, the highest inflow was achieved by the manufacture of food products and beverages, manufacture of motor vehicles, manufacture of rubber and plastic products, and manufacture of chemical products.

Table 6. Payments for investments in the manufacturing industry and its branches, 2010-2015, in EUR million

\begin{tabular}{|l|r|r|r|r|r|r|r|}
\hline Branch & \multicolumn{1}{|c|}{2010} & \multicolumn{1}{|c|}{2011} & \multicolumn{1}{|c|}{2012} & 2013 & 2014 & 2015 & Total \\
\hline Manufacture of coke and oil derivatives & 174.5 & 320.6 & 344.7 & 451.1 & 6.0 & 4.8 & 1,302 \\
\hline Manufacture of food products & 191.4 & 205.2 & 210.8 & 226.4 & 158.7 & 175.1 & 1,168 \\
\hline Manufacture of motor vehicles & 67.1 & 233.9 & 262.1 & 306.8 & 139. & 73.4 & 1,083 \\
\hline Manufacture of rubber and plastic products & 56.8 & 58.5 & 66.6 & 104.1 & 151.2 & 137.2 & 574 \\
\hline Manufacture of metal products & 57.7 & 76.1 & 73.8 & 65.4 & 61.3 & 83.3 & 418 \\
\hline Manufacture of chemicals and chemical products & 32.2 & 46.9 & 72.3 & 79.3 & 60.6 & 66.6 & 358 \\
\hline Manufacture of beverages & 54.5 & 36.5 & 33.3 & 36.6 & 31.6 & 39.6 & 232 \\
\hline Manufacture of non-metal minerals & 45.1 & 35.7 & 48.6 & 40.3 & 25.9 & 29.1 & 225 \\
\hline Manufacture of basic metals & 36.3 & 70.1 & 38.1 & 17.9 & 26.5 & 34.9 & 224 \\
\hline Manufacture of paper and paper products & 20.9 & 15.5 & 33.0 & 65.8 & 32.3 & 42.1 & 210 \\
\hline Other manufacturing branches & 169.6 & 159.5 & 253.5 & 229.2 & 242.7 & 251.8 & 1,306 \\
\hline Manufacturing industry & 906 & 1,259 & 1,437 & 1,623 & 936 & 938 & 7,098 \\
\hline
\end{tabular}

Table 7. FDI per manufacturing industry branches in the period 20102016, in EUR million

\begin{tabular}{|l|r|r|r|r|r|r|r|}
\hline & 2010 & \multicolumn{1}{|c|}{2011} & \multicolumn{1}{c|}{2012} & 2013 & 2014 & 2015 & Total \\
\hline Economy & 1,278 & 3,544 & 1,008 & 1,547 & 1,500 & 2,114 & 10,994 \\
\hline Manufacturing industry & 329.4 & 631.1 & 521.2 & 679.2 & 535.2 & 721.1 & 3,417 \\
\hline $\begin{array}{l}\text { Manufacture of food products, } \\
\text { beverages and tobacco products }\end{array}$ & 38.0 & 249.3 & 157.8 & 166.2 & 108.5 & 122.9 & 842.8 \\
\hline $\begin{array}{l}\text { Manufacture of rubber and } \\
\text { plastic products }\end{array}$ & 67.2 & 93.2 & 151.1 & 186.8 & 172.6 & 141.9 & 812.9 \\
\hline Manufacture of motor vehicles & 10.5 & 70.6 & 14.9 & 31.2 & 37.8 & 140.5 & 305.5 \\
\hline $\begin{array}{l}\text { Manufacture of chemicals and } \\
\text { chemical products }\end{array}$ & 38.2 & 51.2 & 31.2 & 45.8 & 46.3 & 66.6 & 279.3 \\
\hline
\end{tabular}

Source: Authors, based on the Statistical Office of the Republic of Serbia 


\section{Efekti investicija u osnovne fondove Prerađivačke industrije Srbije}

Nivo učešća sektora Prerađivačke industrije u BDV od 15,6\% u 2015. godini pokazuje da se radi o važnom i pojedinačno najvećem sektoru privrede (Tabela 8). Premda ovaj sektor ima relativno najveći doprinos stvaranju BDV privrede on je doživeo jako intenzivan pad učešća od čak $7 \%$ procentnih poena od 2001. godine. Pad je zaustavljen posle 2010. godine zahvaljujući investicijama u pojedine proizvodnje koje su pokrenule strukturne promene prerađivačke industrije. Rezultat je povećanje učešća za 2 procentna poena 2015. godine $u$ odnosu na 2010. godinu i apsolutni rast $\mathrm{BDV}$ za oko 1,1 mlrd. EUR.

Tabela 8. Bruto dodata vrednost (BDV) sektora prerađivačke industrije, 2001-2015. godina

\begin{tabular}{|l|r|r|r|r|r|}
\hline & \multicolumn{1}{|c|}{2001.} & \multicolumn{1}{|c|}{2010.} & \multicolumn{1}{c|}{2015.} & $\Delta 2001$ & $\Delta 2010$ \\
\hline Učešće u BDP, \% & 22,6 & 13,6 & 15,6 & $-7,0$ & 2,0 \\
\hline BDV u mlrd. EUR & 3,1 & 4,1 & 5,2 & 2,1 & 1,1 \\
\hline
\end{tabular}

Izvor: Autori na osnovu RZS

Pored niskog učešća investicija u BDP posebno je niska efikasnost investicionih ulaganja u privredi. Bruto marginalni kapitalni koeficijent (BMKK) pokazuje nisku efikasnost i pad efikasnosti investicionih aktivnosti (Tabela 9). On pokazuje da je u periodu 20012005. godine bilo potrebno 2,23 EUR da bi BDP porastao za jedan EUR. U periodu 2006-2010. godine usled efekata svetske ekonomske krize BMKK je porastao i bilo potrebno 6,2 EUR da bi BDP porastao za jedan EUR, a u periodu 20112015. bilo potrebno čak 44,7 EUR da bi BDP porastao za jedan EUR. Iz ovakvog kretanja efikasnosti investicija potvrđeno je pravilo da se efikasnost menja u vremenu i da na nju utiče veliki broj faktora, počev od ekonomske do tehničke strukture investicija. Ipak, neefikasnosti investicija u privredi još su jedan od pokazatelja brojnih sistemskih ograničenja, koncepta tranzicije, institucionalnih reformi, nepostojanih i zakasnelih strukturnih promena, $\mathrm{Na}$ ovo se nadovezuje i makroekonomska nestabilnost, i posebno negativne stope rasta BDP u tri godine od 2009. (2012. i 2014. godine) što je uticalo da je nivo BDP u 2015. godini na onom iz pred kriznog perioda.
Tabela 9. Bruto marginalni kapitalni koeficijent i koeficijent efikasnosti investicija

\begin{tabular}{|c|c|c|c|}
\hline & $2001-2005$. & 2006-2010. & 2011-2015. \\
\hline & \multicolumn{3}{|c|}{ Privreda } \\
\hline BMKK & 2,23 & 6,16 & 45,10 \\
\hline \multirow[t]{2}{*}{ 1/BMMK } & 44,74 & 16,24 & 2,22 \\
\hline & \multicolumn{3}{|c|}{ Prerađivačka industrija } \\
\hline BMKK & n. p. & 4,15 & 1,62 \\
\hline 1/BMKK & n. p. & 0,24 & 0,62 \\
\hline
\end{tabular}

Ukoliko se posmatra efikasnost investicionih ulaganja sektora prerađivačke industrije ona je na nešto višem nivou u odnosu na privredu. BMKK pokazuje da je u periodu 2006-2010. godine za rast BDV prerađivačke industrije za jedan EUR bilo potrebno da investicije $u$ prerađivačku industriju budu 4,15 EUR. U periodu 2010-2015. godine došlo do povećanja efikasnosti tako da je za rast BDV prerađivačke industrije za jedan EUR bilo potrebno da investicije budu 1,62 EUR.

U Tabeli 10 prikazane su strukturne promene, odnosno kretanje BDV, zaposlenost i zarada u prerađivačkoj industriji u periodu 2010-2015. godina. Sprovedene strukturne promene nisu imale značajnijeg efekta na izmenu strukture. BDV je značajnije povećan u oblastima proizvodnje motornih vozila, proizvodnje koksa i derivata nafte i proizvodnje prehrambenih proizvoda, odnosno oblastima sa najvećim iznosima bruto investicija u osnovne fondove. Ostale oblasti beleže znatno manji rast ili čak i pad BDV.

Broj zaposlenih u prerađivačkoj industriji smanjen je za 24.683 od 2010. godine. U oblasti proizvodnje motornih vozila zabeležen je porast broja zaposlenih za 7.p598 u odnosu na 2010. godinu. Broj radnika je veći i u oblasti proizvodnje tekstila (1.098), proizvodnje odevnih predmeta (2.613), proizvodnje kože i predmeta od kože (644), proizvodnje proizvoda od gume i plastike (925) i oblasti ostale prerađivačke delatnosti (251). Ostale oblasti prerađivačke industrije zabeležile su pad zaposlenosti. Prosečne neto zarade u prerađivačkoj industriji porasle su od 2010. godine za oko 60 EUR u 2015. godini i iznose oko 340 EUR. One su ispod proseka privrede i na njihov niži nivo uticao je i pad zaposlenosti u ovom sektoru, ali i nerealno visok rast $\mathrm{u}$ pred kriznom periodu. Raspon 


\section{Effects of Investment in the Fixed Assets of the Manufacturing Industry of Serbia}

The share of the manufacturing industry in GVA amounting to $15.6 \%$ in 2015 suggests that this is a significant and, by itself, the biggest sector of the economy (Table 8). Although, relatively speaking, this sector contributes the most to generating the GVA of the economy, it experienced a rather intensive drop in its share by as much as 7\% percentage points since 2001 . The downward trend was stopped after 2010 owing to investment into specific products which launched some structural changes in the manufacturing industry. As a result, the share rose by 2 percentage points in 2015 compared to 2010, and the absolute GVA growth by about 1.1 billion EUR was recorded.

Table 8. Gross value added (GVA) of the manufacturing industry, 2001-2015

\begin{tabular}{|l|r|r|r|r|r|}
\hline & \multicolumn{1}{|c|}{2001} & \multicolumn{1}{c|}{2010} & \multicolumn{1}{c|}{2015} & $\Delta 2001$ & $\Delta 2010$ \\
\hline Share in GVA, \% & 22.6 & 13.6 & 15.6 & -7.0 & 2.0 \\
\hline GVA in EUR billion & 3.1 & 4.1 & 5.2 & 2.1 & 1.1 \\
\hline
\end{tabular}
Source: Authors, based on the Statistical Office of the Republic of Serbia

In addition to the low share of investment in GDP, there is a particularly low efficiency of investments into the economy. The gross marginal capital coefficient (GMCC) indicates low efficiency and a declining efficiency of investment activities (Table 9). It suggests that, in the period from 2001 to 2005, it took 2.23 EUR for the GDP to increase by 1 EUR. In the period from 2006 to 2010, due to the effects of the global economic crisis, the GMCC rose, and it took 6.2 EUR for the GDP to increase by 1 EUR, whereas in the period from 2011 to 2015 it took as much as 44.7 EUR for the GDP to increase by 1 EUR. Such trends of the investment efficiency confirm the rule that efficiency changes over time and is affected by a large number of factors, ranging from the economic to technical structure of investment. Nonetheless, the inefficiency of economic investment is another indicator of the numerous systemic limitations, concept of transition, institutional reform, non-existent and belated structural changes. All this is against the background of macroeconomic instability, particularly the negative GDP growth rates in three years since 2009 (in 2012 and 2014), which altogether contributed to the GDP in 2015 being at the same level as before the crisis.

Table 9. Gross marginal capital coefficient and investment efficiency ratio

\begin{tabular}{|c|c|c|c|}
\hline & 2001-2005 & $2006-2010$ & 2011-2015 \\
\hline & \multicolumn{3}{|c|}{ Economy } \\
\hline GMCC & 2.23 & 6.16 & 45.10 \\
\hline \multirow[t]{2}{*}{ 1/GMCC } & 44.74 & 16.24 & 2.22 \\
\hline & \multicolumn{3}{|c|}{ Manufacturing industry } \\
\hline GMCC & n.a. & 4.15 & 1.62 \\
\hline 1/GMCC & n.a. & 0.24 & 0.62 \\
\hline
\end{tabular}

n.a. - not available

Source: Authors, based on the Statistical Office of the Republic of Serbia

Concerning the efficiency of investments in the manufacturing industry, it is slightly higher in relation to the economy. The marginal capital coefficient shows that, from 2006 to 2010,

in order for the manufacturing industry's GVA to increase by $1 \mathrm{EUR}$, the investments into the manufacturing industry had to amass to 4.15 EUR. In the period from 2010 to 2015 efficiency recorded an upward trend, hence the increase of the manufacturing industry's GVA by 1 EUR required investments of 1.62 EUR.

Table 10 shows the structural changes, i.e. the movement of the GVA, employment rate and earnings in the manufacturing industry from 2010 to 2015. The implemented changes had no significant effect on the change of structure. The GVA experienced a more noticeable growth in the branches of the motor vehicle manufacture, coke and oil derivatives manufacture and food manufacture, which is to say, in the branches with the highest gross investments into fixed assets. Other branches showed a significantly slighter growth or even a decline in the GVA.

The number of employees in the manufacturing industry was reduced by 24,683 in 2010. In the field of motor vehicle manufacture, an increase of 7,598 was recorded in the number of employees, in comparison to 2010. There are more employees in the textile manufacturing industry (1,098), clothing manufacturing industry $(2,631)$, leather and leather products manufacturing industry (644), rubber and plastic manufacturing industry (925) and in other manufacturing fields (251). The remaining fields of the manufacturing 
kretanja zarada po oblastima prerađivačke industrije je jako veliki i kreće se od 897 EUR u proizvodnji koksa i derivata nafte do 198 EUR u proizvodnji odevnih predmeta. Zanimljivo da su u oblasti proizvodnje motornih vozila prosečne neto zarade u 2015. godini iznosile 294 EUR što se jedino može tumačiti jeftinijom radnom snagom, odnosno da su veće bruto investicije u osnovne fondove i veći priliv stranih investicija u ovoj oblasti rezultat nižih troškova radne snage u Srbiji. bude jedan od najvažnijih faktora oporavka i strukturnih promena prerađivačke industrije, odnosno njenog održivog rasta, rasta broja zaposlenih, tehnološke modernizacije, povećanja produktivnosti i konkurentnosti i izvoza. Za ostvarivanje ovakvih zadataka potrebno je učešce investicija od 25 do $30 \%$ u BDP-u, ili učešće bruto investicija prerađivačke industrije prosečno od 7 do $8 \%$ godišnje u BDP-u. Da bi se ostvarili prethodni zadaci neophodan je i rast efikasnosti investicionih ulaganja u privredi, ali

Tabela 10. BDV, zaposlenost i zarade u sektoru prerađivačke industrije, 2010-2015.

\begin{tabular}{|c|c|c|c|c|c|c|}
\hline & \multicolumn{2}{|c|}{$\begin{array}{c}\text { BDV u milionima } \\
\text { EUR }\end{array}$} & \multicolumn{2}{|c|}{ Broj zaposlenih } & \multicolumn{2}{|c|}{$\begin{array}{l}\text { Prosečne neto } \\
\text { zarade } \mathrm{u} \text { EUR }\end{array}$} \\
\hline & 2015. & $\Delta 2010$ & 2015. & $\Delta 2010$ & 2015. & $\Delta 2010$ \\
\hline Privreda ukupno & 27.716 & 2.897 & 1.896 .295 & -4.903 & 368 & 37 \\
\hline Prerađivačka industrija & 5.232 & 1.171 & 380.325 & -24.683 & 341 & 59 \\
\hline - Proizvodnja prehrambenih proizvoda & 1.088 & 179 & 82.822 & -3.298 & 316 & 44 \\
\hline - Proizvodnja pića & 290 & 29 & 8.341 & -3.275 & 544 & 80 \\
\hline - Proizvodnja duvanskih proizvoda & 44 & -4 & 1.196 & -405 & 884 & 180 \\
\hline - Proizvodnja tekstila & 64 & 9 & 10.040 & 1.098 & 271 & 93 \\
\hline - Proizvodnja odevnih predmeta & 213 & 54 & 32.593 & 2.613 & 198 & 30 \\
\hline - Proizvodnja kože i predmeta od kože & 68 & 1 & 11.454 & 644 & 228 & 42 \\
\hline - Prerada drveta i proizvodi od drveta & 123 & 37 & 14.336 & -411 & 214 & 63 \\
\hline - Proizvodnja papira i proizvoda od papira & 137 & 31 & 70.39 & -1.258 & 439 & 124 \\
\hline - Štampanje i umnožavanje & 91 & -7 & 8.852 & -965 & 300 & 58 \\
\hline - Proizvodnja koksa i derivata nafte & 419 & -3 & 1761 & -1.496 & 897 & 277 \\
\hline - Proizvodnja hemikalija i hemijskih proizvoda & 324 & 235 & 13.114 & -2.936 & 421 & 62 \\
\hline - Proizvodnja osnovnih farmaceutskih proizvoda & 112 & -32 & 4.193 & -1.499 & 687 & 74 \\
\hline - Proizvodnja proizvoda od gume i plastike & 388 & 122 & 22.523 & 925 & 403 & 101 \\
\hline - Proizvodnja proizvoda od nemetalnih minerala & 217 & -15 & 13.146 & -5.982 & 395 & 92 \\
\hline - Proizvodnja osnovnih metala & 125 & 59 & 12.542 & -5.267 & 426 & 40 \\
\hline - Proizvodnja metalnih proizvoda & 408 & 38 & 39.504 & -3.484 & 320 & 75 \\
\hline - Proizvodnja računara & 116 & -3 & 8.245 & -3.794 & 687 & 443 \\
\hline - Proizvodnja električne opreme & 145 & 24 & 14.918 & -1.069 & 310 & 39 \\
\hline - Proizvodnja nepomenutih mašina i opreme & 231 & 86 & 15.555 & -3.643 & 400 & 110 \\
\hline - Proizvodnja motornih vozila & 349 & 272 & 25.658 & 7.598 & 294 & 62 \\
\hline - Proizvodnja ostalih saobraćajnih sredstava & 22 & -3 & 4.769 & -480 & 305 & 55 \\
\hline - Proizvodnja nameštaja & 100 & 3 & 13.972 & -805 & 221 & 44 \\
\hline - Ostale prerađivačke delatnosti & 78 & 17 & 7.721 & 251 & 313 & 133 \\
\hline - Popravka i montaža mašina i opreme & 81 & 43 & 3.037 & -739 & 313 & 80 \\
\hline
\end{tabular}

\section{Zaključak}

Generalno, nivo investicija je nizak u odnosu na razvojne potrebe privrede i prerađivačke industrije Srbije i pored apsolutnog i relativnog rasta bruto investicija $\mathrm{u}$ osnovne fondove privrede i prerađivačke industrije $u$ periodu 2001-2015. godine. Investiciona aktivnost je niska i u odnosu na države iz okruženja, nove članice EU i prosek EU-28. U narednom periodu oslonac na sopstvene snage i rast ukupnog nivoa investicija $\mathrm{u}$ osnovne fondove i treba da i u prerađivačkoj industriji, iako je ona na višem nivou u odnosu na privredu. Bruto marginalni kapitalni koeficijent pokazuje nisku efikasnost, pa čak i pad efikasnosti investicionih aktivnosti u pojedinim periodima, posebno u privredi.

U narednom periodu ulogu SDI ne bi trebalo potcenjivati, ali ni precenjivati u strukturnim promenama i modernizaciji prerađivačke industrije. SDI treba da budu ciljane i usmeravane u privlačenje novih digitalnih tehnologija i razvoj Industrija 4.0. čime bi se ostvario najveći efekat na održivi razvoj privrede. 
industry recorded decreased employment rates. Average net earnings in the manufacturing industry increased in 2010 by around 60 EUR, and amounted to about 340 EUR in 2015. They are below the economy's average and their decrease was influenced by a decreasing trend in employment rates, as well as the unrealistically large growth in the pre-crisis period. Earnings differed to a great extent depending on the field of the manufacturing industry, ranging from 897 EUR in the coke and oil derivative manufacture industry to 198 EUR in the clothing manufacturing industry. It is interesting to note that the average net earnings in the field of motor vehicle manufacture for 2015 amounted to 294 EUR, which can only be explained by cheaper labour force, i.e. that larger gross investments into fixed assets and the larger inflow of foreign investments in this field resulted in lower labour force costs in Serbia.

\section{Conclusion}

In general, the level of investments is low in relation to the developmental necessities of the economy and the manufacturing industry of Serbia, despite the absolute and relative growth of gross investments into fixed assets of the economy and the manufacturing industry from 2001 to 2015. Investment activity is also low in comparison to the neighbouring countries, the new EU members and the EU-28 average. In the coming period, the reliance on one's own strengths and the increase in the total level of investments into fixed assets should indeed be one of the key factors of recovery and structural changes of the manufacturing industry: its sustainable growth, technological modernisation, increase in productivity, position on the market and export. In order to achieve these goals, the share of investments in

Table 10. GVA, employment and salaries in the manufacturing industry, 2010-2015

\begin{tabular}{|c|c|c|c|c|c|c|}
\hline & \multicolumn{2}{|c|}{$\begin{array}{l}\text { GVA in EUR } \\
\text { million }\end{array}$} & \multicolumn{2}{|c|}{$\begin{array}{l}\text { Number of } \\
\text { employees }\end{array}$} & \multicolumn{2}{|c|}{$\begin{array}{c}\text { Average net } \\
\text { salaries in EUR }\end{array}$} \\
\hline & 2015 & $\Delta 2010$ & 2015 & $\Delta 2010$ & 2015 & $\Delta 2010$ \\
\hline Economy in total & 27,716 & 2,897 & $1,896,295$ & $-4,903$ & 368 & 37 \\
\hline Manufacturing industry & 5,232 & 1,171 & 380,325 & $-24,683$ & 341 & 59 \\
\hline - Manufacture of food products & 1,088 & 179 & 82,822 & $-3,298$ & 316 & 44 \\
\hline - Manufacture of beverages & 290 & 29 & 8,341 & $-3,275$ & 544 & 80 \\
\hline - Manufacture of tobacco products & 44 & -4 & 1,196 & -405 & 884 & 180 \\
\hline - Manufacture of textile & 64 & 9 & 10,040 & 1,098 & 271 & 93 \\
\hline - Manufacture of clothes & 213 & 54 & 32,593 & 2,613 & 198 & 30 \\
\hline - Manufacture of leather and leather products & 68 & 1 & 11,454 & 644 & 228 & 42 \\
\hline - Processing of wood and wood products & 123 & 37 & 14,336 & -411 & 214 & 63 \\
\hline - Manufacture of paper and paper products & 137 & 31 & 70,39 & $-1,258$ & 439 & 124 \\
\hline - Printing and reproduction & 91 & -7 & 8,852 & -965 & 300 & 58 \\
\hline - Manufacture of coke and oil derivatives & 419 & -3 & 1761 & $-1,496$ & 897 & 277 \\
\hline - Manufacture of chemicals and chemical products & 324 & 235 & 13,114 & $-2,936$ & 421 & 62 \\
\hline - Manufacture of basic pharmaceutical products & 112 & -32 & 4,193 & $-1,499$ & 687 & 74 \\
\hline - Manufacture of rubber and plastic products & 388 & 122 & 22,523 & 925 & 403 & 101 \\
\hline - Manufacture of non-metal minerals & 217 & -15 & 13,146 & $-5,982$ & 395 & 92 \\
\hline - Manufacture of basic metals & 125 & 59 & 12,542 & $-5,267$ & 426 & 40 \\
\hline - Manufacture of metal products & 408 & 38 & 39,504 & $-3,484$ & 320 & 75 \\
\hline - Manufacture of computers & 116 & -3 & 8,245 & $-3,794$ & 687 & 443 \\
\hline - Manufacture of electrical equipment & 145 & 24 & 14,918 & $-1,069$ & 310 & 39 \\
\hline - Manufacture of machines and equipment & 231 & 86 & 15,555 & $-3,643$ & 400 & 110 \\
\hline - Manufacture of motor vehicles & 349 & 272 & 25,658 & 7,598 & 294 & 62 \\
\hline - Manufacture of other transportation equipment & 22 & -3 & 4,769 & -480 & 305 & 55 \\
\hline - Manufacture of furniture & 100 & 3 & 13,972 & -805 & 221 & 44 \\
\hline - Other manufacturing branches & 78 & 17 & 7,721 & 251 & 313 & 133 \\
\hline - Repair and installment of machines and equipment & 81 & 43 & 3,037 & -739 & 313 & 80 \\
\hline
\end{tabular}




\section{Literatura / References}

1. Antevski, M., (2008), Strane direktne investicije: karakteristike, obrasci i efekti. Međunarodni problemi, 60 (1)

2. Antevski, M., (2009), Razvojni potencijali stranih direktnih investicija. Međunarodni problemi, 61 (1-2)

3. Chen, K., Jefferson, G. H., Rawski, T. G., Wang, H., \& Zheng, Y. (1988). New estimates of fixed investment and capital stock for Chinese state industry. The China Quarterly, 114, 243-266

4. Erić, D. D., Beraha, I. A., Đuričin, S. O., Kecman, N. Đ., \& Jakišić, B. B. (2012). Finansiranje malih i srednjih preduzeća u Srbiji, Alternationi izvori finansiranja konceptualni okvir za razumevanje rizičnog kapitala (venture capital) i privatni investicioni fondovi (Private equity funds), Beograd: Institut ekonomskih nauka i Privredna komora Srbije, 71-79.

5. European Commission (EC). (2017). Database. Brussels, Belgium: EC.

6. Faulkender, M., \& Petersen, M. A. (2006). Does the Source of Capital Affect Capital Structure? . Review of financial studies, 19 (1), 45-79.

7. Gompers, P., \& Lerner, J. (2001). The venture capital revolution. The Journal of Economic Perspectives, 15 (2), 145-168.

8. Hellmann, T., \& Puri, M. (2000). The interaction between product market and financing strategy: The role of venture capital. Review of Financial studies, 13 (4), 959-984.

9. Ilić, M. Savić, Lj. Cvetanović, S. \& Arsovski, Z. (2003), Industrijski menadžment, Kragujevac: Ekonomski fakultet Univerziteta u Kragujevcu.

10. Inderst, G. (2013). Private infrastructure finance and investment in Europe, EIB Working Papers 2013/2, 28-33.
11. Jovanović Gavrilović, P., (2012), Međunarodno poslowno finansiranje, Ekonomski fakultet. Beograd

12. Narodna banka Srbije (NBS). (2017). Statistika. Beograd, Srbija: RZS.

13. Republički zavod za statistiku (RZS). (2016), Statistički godišnjak Republike Srbije 2016, Nacionalni račun, Beograd.

14. Republički zavod za statistiku (RZS). (2017). Statistička baza podataka. Beograd, Srbija: RZS.

15. Rowthorn, R. (1995). Capital Formation and Unemployment. Oxford Review of Economic Policy, 11 (1), 26-39.

16. Savić, Lj. Ilić, M. \& Mićić, V. (2015), Ekonomika industrije, Kragujevac: Ekonomski fakultet Univerziteta u Kragujevcu.

17. Sokoloff, K. L. (1984). Investment in Fixed and Working Capital During Early Industrialization: Evidence from US Manufacturing Firms. The Journal of Economic History, 44 (02), 545-556.

18. United Nations Industrial Development Organization. (UNIDO). (2015). Industrial Development Report 2016. The Role of Technology and Innovation in Inclusive and Sustainable Industrial Development. Vienna.

19. United Nations Industrial Development Organization. (UNIDO). (2013). Industrial Development Report 2013, Sustaining Employment Growth: The Role of Manufacturing and Structural Change. Vienna.

20. Veselinović, P., (2004), “Uticaj stranih direktnih investicija na razvoj nacionalne ekonomije", Ekonomski horizonti 6, Ekonomski fakultet Univerziteta $\mathrm{u}$ Kragujevcu

21. Wurgler, J. (2000). Financial Markets and the Allocation of Capital. Journal of Financial Economics, 58 (1), 187-214. 
the GDP needs to be $25-30 \%$, or the share of gross investments in the manufacturing industry in the GDP needs to have an annual average of 7 to $8 \%$. In order to accomplish the previous goals, the increase in the efficiency of investments is necessary, both into the economy, as well as the manufacturing industry, although the latter's is at a higher level. The gross marginal capital coefficient shows low, even declining efficiency of investment activity over certain periods, especially in the economy.
In the forthcoming period, the role of FDI should not be underestimated, but neither should it be overestimated in terms of the structural changes and modernisation of the manufacturing industry. FDI should be directed towards attracting new digital technologies and developing Industry 4.0, which would have the largest effect on the sustainable development of the economy. 